\title{
Genotoxicity assessment of the antimalarial compound artesunate in somatic cells of mice
}

\author{
Ivani Aquino ${ }^{\mathrm{a}}$, Fábio Ferreira Perazzo ${ }^{\mathrm{b}}$, Edson Luis Maistro ${ }^{\mathrm{c}, *}$ \\ a Universidade Estadual Paulista - UNESP - Instituto de Biociências, Programa de Pós-Graduação em Biologia Geral e Aplicada, Botucatu, SP 18618-970, Brazil \\ ${ }^{\mathrm{b}}$ Universidade Federal de São Paulo - Unifesp, Departamento de Ciências Exatas e da Terra, Diadema, SP 09972-270, Brazil \\ ' Universidade Estadual Paulista - UNESP - Faculdade de Filosofia e Ciências, Departamento de Fonoaudiologia, Marília, SP 17525-900, Brazil
}

\section{A R T I C L E I N F O}

\section{Article history:}

Received 26 January 2011

Accepted 13 March 2011

Available online 17 March 2011

\section{Keywords:}

Artesunate

Artemisinin derivate

Micronucleus test

comet assay

Clastogenicity

\begin{abstract}
A B S T R A C T
Artesunate is a derivate of artemisinin that is both an antimalarial agent and acts cytotoxically on tumor cells. Despite its therapeutic use, its in vivo genotoxic potential has still not been evaluated. This study, therefore, was an investigation into the effects of a single oral administration of artesunate with an in vivo comet assay that analyzed leukocytes from peripheral blood and liver cells, and a micronucleus (MN) assay of bone marrow cells from male Swiss mice. The artesunate was administered by oral gavage at doses of 5,50 and $100 \mathrm{mg} / \mathrm{kg}$. Cytotoxicity was assessed by scoring 200 consecutive polychromatic (PCE) and normochromatic (NCE) erythrocytes (PCE/NCE ratio). The results demonstrate that artesunate induced significant DNA damage only in liver cells and that high doses of artesunate caused an increase in the mean number of micronucleated polychromatic erythrocytes (MNPCE). Under our experimental conditions, artesunate showed weak genotoxic effects at low doses and clastogenic effects at high doses. The PCE/NCE ratio indicated no cytotoxicity. The data obtained suggest caution about either continuous or high-dose use of artesunate by humans.
\end{abstract}

(C) 2011 Elsevier Ltd. Open access under the Elsevier OA license.

\section{Introduction}

Malaria is the most devastating endemic tropical disease in the world, with between 300 and 500 million clinical cases and almost three million deaths every year. Most of these deaths are caused by infection with Plasmodium falciparum, the most harmful species of malaria parasite (WHO, 2001). The main active principle of the Artemisia annua plant is known as artemisinin (Klayman, 1985). Artemisinin and its derivatives, such as artesunate, stand out among the chemotherapy medicine available for the treatment and chemoprophylaxis of malaria because this anti-malarial medicine presents no clinically relevant resistance to plasmodium (Meshnick et al., 1996; Dhingra et al., 2000; Olliaro, 2001). Artemisinin has been chemically modified to produce derivatives such as: sodium artesunate, artemether, arteether, dihydroartemisinin, and artelinic acid. These compounds have been formulated for oral, rectal, and parenteral administration. Combinations of these medicines have presented fast antimalarial activity and an absence of clinically important resistance (Woodrow et al., 2005). Artesunate is the most versatile of these derivatives, because it is easily soluble in water, which has facilitated the development of oral and rectal formulas, and thus is often used both in monotherapy and combined with other drugs (WHO, 2001; Angus et al., 2002).

\footnotetext{
* Corresponding author. Tel.: +55 2114 34021324; fax: +55 211434021302

E-mail address: edson.maistro@marilia.unesp.br (E.L. Maistro).
}

The combination of oral artesunate and mefloquine is commonly used to treat malaria in Southeast Asia. The addition of artesunate accelerates the therapeutic response, reduces recrudescence rates and transmissibility, prevents the occurrence of resistance, increases patient compliance, and also provides a highly effective treatment for hyperparasitemic patients and recrudescent infections (Nosten et al., 1994, 2000; Luxemburguer et al., 1995; Price et al., 1995).

The combination of artesunate and amodiaquine is an ACT (artemisinin-based combination therapy) recommended by the World Health Organization (WHO) for use in malaria control programs, and is a first-line treatment for African children with non-complicated malaria (WHO, 2004).

Considering the use of artesunate in the treatment of malaria and the inexistence of in vivo mammal cell studies investigating its genetic toxicity, the main objective of this study was to evaluate the genotoxic/mutagenic potential of artesunate in the peripheral blood cells, liver and bone marrow of male albino (Mus musculus) Swiss mice, using the comet assay (SCGE) and the micronucleus test.

\section{Materials and methods}

\subsection{Artesunate}

Dihydroartemisinin was prepared from artemisinin using a routine procedure (Brossi et al., 1988). The acid chloride $\mathrm{RCOCl}$ was prepared from the corresponding carboxylic acids by heating them with thionyl chloride at $50-60{ }^{\circ} \mathrm{C}$ for $2-3 \mathrm{~h}$ and 
reacting them with dihydroartemisinin in the presence of triethylamine in dry dichloromethane at $0{ }^{\circ} \mathrm{C}$ for $2 \mathrm{~h}$ to furnish ester derivatives in $49-58 \%$ yields. Artesunate was prepared from dihydroartemisinin (DHA) by reacting it with succinic acid anhydride in basic medium. Pyridine was used as a solvent, sodium bicarbonate as a base and DMAP ( $N, N$-dimethylaminopyridine) and triethylamine in 1,2dichloroethane were used as catalysts, with yields of up to $100 \%$. The mixture was stirred up to $9 \mathrm{~h}$ to obtain artesunate in quantitative yield. The product was further re-crystallized from dichloromethane. Alpha-Artesunate was exclusively formed (m.p. $\left.135-137^{\circ} \mathrm{C}\right)$.

\subsection{Chemicals}

Doxorubicin (DXR, Oncodox ${ }^{\circledR}$, Meizler) was used as the DNA damaging agent in the comet and micronucleus assays, and was prepared by dissolving in sterile water. The other main chemicals were obtained from the following suppliers: normal melting point (NMP) agarose (Cat. No. 15510-019: Invitrogen) low melting point (LMP) agarose (Cat. No. 15517-014: Invitrogen), sodium salt N-lauroyl sarcosine (L-5125: Sigma) and ethylenediaminetetraacetic acid (EDTA) (Merck).

\subsection{Animals and dosing}

Experiments were carried out on 12-week old male Swiss albino mice (Mus musculus), weighing 25-30 g. The animals were acquired from the animal house of the Universidade Estadual Paulista (UNESP), Botucatu, São Paulo, Brazil and kept in polyethylene boxes $(n=6)$ in a climate-controlled environment $\left(25 \pm 4{ }^{\circ} \mathrm{C}\right.$, $55 \pm 5 \%$ humidity) with a $12 \mathrm{~h}$ light/dark cycle ( 7 a.m. -7 p.m.). Food (NUVILAB CR1 - NUVITAL) and water were available ad libitum. The mice were divided into experimental groups of six animals/box. Artesunate was diluted in water and administered in a single dose of $0.5 \mathrm{~mL}$ by gavage at concentrations of 5,50 and $100 \mathrm{mg} / \mathrm{kg}$ body weight. These concentrations were based on our acute toxicity studies in mice, as well as on studies of its antimalarial effects (Angus et al., 2002). The negative control group received distilled water. The positive control group received an intraperitoneal injection of Doxorubicin $80 \mathrm{mg} / \mathrm{kg}$. The animals used in this study were sacrificed by cervical dislocation. The experimental design is presented in Table 1. The Animal Bioethics Committee of FAMEMA, Marília, Brazil, approved this study on July 30, 2009 (protocol number 140/09), in accordance with federal government legislation on animal care.

\section{4. comet assay}

The comet assay (SCGE) was carried out according to the method described by Speit and Hartmann (1999), which is based on the original work of Singh et al. (1988), and the guidelines discussed by Tice et al. (2000), as well as additional modifications. Twenty-four hours after the treatment, peripheral blood leukocytes and liver cells from six Swiss mice from each group were sampled. Liver samples were washed in saline solution, in an ice bath. A small portion was transferred to a Petri dish containing $1 \mathrm{~mL}$ of Hank's solution ( $\mathrm{pH} 7.5$ ) and then homogenized gently with small pinches. A $10-\mu \mathrm{L}$ aliquot of cells from each animal was mixed with $120 \mu \mathrm{L}$ of $0.5 \%$ low melting point agarose at $37^{\circ} \mathrm{C}$, and immediately spread on microscope slides pre-coated with $1.5 \%$ normal melting point agarose. Coverslips were added and the slides were allowed to gel at $4{ }^{\circ} \mathrm{C}$ for $20 \mathrm{~min}$. The coverslips were gently removed and the slides were then immersed in cold, freshly prepared lysing solution consisting of $89 \mathrm{~mL}$ of a stock solution $(2.5 \mathrm{M} \mathrm{NaCl}, 100 \mathrm{mM}$ EDTA, $10 \mathrm{mM}$ Tris, $\mathrm{pH}$ set to 10.0 with $\sim 8 \mathrm{~g}$ solid $\mathrm{NaOH}, 890 \mathrm{~mL}$ of distilled water and $1 \%$ sodium lauryl sarcosine), plus $1 \mathrm{~mL}$ of Triton X-100 (Merck) and $10 \mathrm{~mL}$ of dimethylsulfoxid (Merck). The slides, which were protected from light, were kept at $4{ }^{\circ} \mathrm{C}$ for $1 \mathrm{~h}$ and then placed in the gel box, positioned at the anode end, and immersed in a high $\mathrm{pH}(>13)$ electrophoresis buffer ( $300 \mathrm{mM} \mathrm{NaOH}$ per $1 \mathrm{mM}$ EDTA, prepared from a stock solution of $10 \mathrm{~N} \mathrm{NaOH}$ and $200 \mathrm{mM}, \mathrm{pH} 10.0$, EDTA) at $4{ }^{\circ} \mathrm{C}$ for $20 \mathrm{~min}$ prior to electrophoresis in order to allow the DNA to unwind. The electrophoresis run was carried out in an ice bath $\left(4^{\circ} \mathrm{C}\right)$ for $20 \mathrm{~min}$ at $300 \mathrm{~mA}$ and $25 \mathrm{~V}\left(0.722 \mathrm{~V} \mathrm{~cm}^{-1}\right)$. The slides were then submerged in a neutralization buffer $(0.4 \mathrm{M}$ Tris- $\mathrm{HCl}, \mathrm{pH} 7.5)$ for $15 \mathrm{~min}$, dried at room temperature and fixed in $100 \%$ ethyl alcohol for $10 \mathrm{~min}$. The slides were dried and stored overnight or longer before staining. For the staining process, each slide was briefly rinsed in distilled water, covered with $30 \mu \mathrm{L}$ of $1 \times$ ethidium bromide staining solution prepared from a $10 \times$ stock $(200 \mu \mathrm{g} / \mathrm{ml})$ and covered with a coverslip. The material was evaluated immediately at $400 \times$ magnification, using a fluorescence microscope (Olympus BX 50) with a 515-560 nm excitation filter and a $590 \mathrm{~nm}$ barrier filter.

The extent and distribution of DNA damage indicated by the SCGE assay was evaluated by examining at least 100 randomly selected and non-overlapping cells (50 cells per coded slide) per animal in a blind analysis (six mice per group). These cells were scored visually, according to tail size, into the following four classes: class 0 no tail; class 1 - tail shorter than the diameter of the head (nucleus); class 2 - tail length 1-2 times the diameter of the head; and class 3 - tail length more than twice the diameter of the head. Comets with no heads, with nearly all of the DNA in the tail or with a very wide tail were excluded from the evaluation because they probably represented dead cells (Hartmann and Speit, 1997). The total score for 100 comets, which ranged from 0 (all undamaged) to 300 (all maximally damaged), was obtained by multiplying the number of cells in each class by the damage class.

\subsection{Micronucleus assay}

The assay was carried out following standard protocols, as recommended by Schmid (1975) and Krishna and Hayashi (2000). The same six mice per group used in the comet assay were used in the micronucleus test. Animals were sacrificed $24 \mathrm{~h}$ after the treatment. The bone marrow from both femurs was flushed out using $2 \mathrm{~mL}$ of saline solution $(\mathrm{NaCl} 0.9 \%$ ) and centrifuged for $7 \mathrm{~min}$. The supernatant was discarded and smears were made. The slides were coded for a "blind" analysis, fixed with methanol and stained with Giemsa solution. For the micronucleated cell analysis, 2000 polychromatic erythrocytes (PCE) per animal were scored to determine the mutagenic effects of artesunate. To detect possible cytotoxic effects, the PCE/ NCE (polychromatic/normochromatic erythrocyte) ratio from 200 erythrocytes/animal was calculated (Gollapudi and McFadden, 1995). Coded slides were scored with a light microscope at $1000 \times$ magnification. The mean number of micronucleated polychromatic erythrocytes (MNPCE) in individual mice was used as the experimental unit, with variability (standard deviation) based on intragroup differences among animals.

\subsection{Statistical analysis}

After verifying for normal distribution, the data obtained from micronucleus and SCGE assays were submitted to one-way analysis of variance (ANOVA) and the Tukey-Kramer multiple comparison test (Sokal and Rohlf, 1995) with the GraphPad Instat ${ }^{\circledR}$ software (version 3.01). The results were considered statistically significant at $P<0.05$.

\section{Results}

The comet assay results are shown in Tables 1 and 2, where the animals results for the different doses of artesunate and DXR-positive control are compared with the negative control (water). As expected, when the positive control was compared with the negative control, we found that DXR induced a significant increase $(P<0.001$ or greater) in comet assay DNA migration for leukocyte and liver cells (Tables 1 and 2). We found a significant increase in DNA migration only at a 5 and $50 \mathrm{mg} / \mathrm{kg}$ dose in liver cells. There was no statistical difference in DNA migration between the three tested doses of artesunate. At the dosage that induced a significant increase in DNA damage in liver cells cells, most of the damage was minor (class 1 ), with only a very few cells showing a large amount of damage (classes 2 and 3 ).

Table 3 shows the micronucleus test results obtained for male Swiss mice treated with artesunate: the mean number of micronucleated polychromatic erythrocytes (MNPCE) in untreated controls and treated animals. As expected, the positive mutagen DXR induced a statistically significant increase in MNPCE. The clastogenicity test revealed an increase in the mean number of MNPCE at all tested doses, being statistically significant at the two highest doses. The observed clastogenicity was dose-related. The tested substance no caused a statistically significant decrease in PCE/NCE ratios. These data suggest that artesunate had a weak clastogenic effect on the bone marrow cells of mice without cytotoxic effects.

\section{Discussion}

Before the approval of new pharmaceutical products, either natural or synthetic, both their therapeutic and their toxicological effects must be evaluated, so that only substances free from potential mutagenic effects are introduced (Rodeiro et al., 2006). Several studies have suggested that mutagenic agents produce carcinogenic effects (Chandra et al., 2006). The combined use of the comet Assay and micronucleus test in a single study has yielded good results. Vasquez (2010), using the damage-inducing agents Mitomycin $\mathrm{C}$ and Cyclophosphamide, tested both techniques concomitantly on different tissues of rats and mice, and thus reduced the number of animals used without compromising the efficacy of the test.

Through the comet assay, it is possible to quantify and distinguish different DNA damage levels, seeing that the evaluation of scores for each experimental group is highly important. In this 
Table 1

DNA migration in the comet assay for the assessment of genotoxicity of artesunate in peripheral blood cells (collected $24 \mathrm{~h}$ after the treatment) from Swiss mice male (M) in vivo.

\begin{tabular}{|c|c|c|c|c|c|c|c|}
\hline \multirow[t]{2}{*}{ Treatments } & \multirow[t]{2}{*}{ Animals } & \multirow[t]{2}{*}{ Total $^{\mathrm{a}}$} & \multicolumn{4}{|c|}{ Comet class } & \multirow[t]{2}{*}{ Scores } \\
\hline & & & 0 & 1 & 2 & 3 & \\
\hline \multirow[t]{7}{*}{ Control } & $\mathrm{M}_{1}$ & 11 & 89 & 11 & 0 & 0 & 11 \\
\hline & $\mathrm{M}_{2}$ & 9 & 91 & 9 & 0 & 0 & 9 \\
\hline & $\mathrm{M}_{3}$ & 8 & 92 & 8 & 0 & 0 & 8 \\
\hline & $\mathrm{M}_{4}$ & 9 & 91 & 9 & 0 & 0 & 9 \\
\hline & $\mathrm{M}_{5}$ & 11 & 89 & 11 & 0 & 0 & 11 \\
\hline & $\mathrm{M}_{6}$ & 12 & 88 & 12 & 0 & 0 & 12 \\
\hline & Mean \pm SD & $10.0 \pm 1.54$ & & & & & $10.0 \pm 1.54$ \\
\hline \multirow[t]{7}{*}{ Artesunate $(5 \mathrm{mg} / \mathrm{kg})$} & $\mathrm{M}_{1}$ & 1 & 99 & 1 & 0 & 0 & 1 \\
\hline & $\mathrm{M}_{2}$ & 3 & 97 & 3 & 0 & 0 & 3 \\
\hline & $\mathrm{M}_{3}$ & 6 & 94 & 6 & 0 & 0 & 6 \\
\hline & $\mathrm{M}_{4}$ & 8 & 92 & 7 & 1 & 0 & 9 \\
\hline & $\mathrm{M}_{5}$ & 4 & 96 & 4 & 0 & 0 & 4 \\
\hline & $\mathrm{M}_{6}$ & 6 & 94 & 6 & 0 & 0 & 6 \\
\hline & Mean \pm SD & $4.66 \pm 2.50$ & & & & & $4.83 \pm 2.78$ \\
\hline \multirow[t]{7}{*}{ Artesunate $(50 \mathrm{mg} / \mathrm{kg})$} & $\mathrm{M}_{1}$ & 5 & 95 & 4 & 1 & 0 & 6 \\
\hline & $\mathrm{M}_{2}$ & 6 & 94 & 4 & 2 & 0 & 8 \\
\hline & $\mathrm{M}_{3}$ & 4 & 96 & 3 & 1 & 0 & 5 \\
\hline & $\mathrm{M}_{4}$ & 1 & 99 & 1 & 0 & 0 & 1 \\
\hline & $\mathrm{M}_{5}$ & 4 & 96 & 4 & 0 & 0 & 4 \\
\hline & $\mathrm{M}_{6}$ & 2 & 98 & 2 & 0 & 0 & 2 \\
\hline & Mean \pm SD & $3.66 \pm 1.86$ & & & & & $4.33 \pm 2.58$ \\
\hline \multirow[t]{7}{*}{ Artesunate (100 mg/kg) } & $\mathrm{M}_{1}$ & 5 & 94 & 3 & 2 & 0 & 7 \\
\hline & $\mathrm{M}_{2}$ & 2 & 98 & 2 & 0 & 0 & 2 \\
\hline & $\mathrm{M}_{3}$ & 5 & 95 & 4 & 1 & 0 & 6 \\
\hline & $\mathrm{M}_{4}$ & 4 & 96 & 4 & 0 & 0 & 4 \\
\hline & $\mathrm{M}_{5}$ & 1 & 99 & 1 & 0 & 0 & 1 \\
\hline & $\mathrm{M}_{6}$ & 3 & 97 & 3 & 0 & 0 & 3 \\
\hline & Mean \pm SD & $3.33 \pm 1.63$ & & & & & $3.83 \pm 2.31$ \\
\hline \multirow[t]{7}{*}{ Doxorubicin $(80$ mg/kg) } & $\mathrm{M}_{1}$ & 97 & 3 & 36 & 39 & 22 & 180 \\
\hline & $\mathrm{M}_{2}$ & 98 & 2 & 42 & 40 & 16 & 170 \\
\hline & $\mathrm{M}_{3}$ & 98 & 2 & 33 & 34 & 31 & 194 \\
\hline & $\mathrm{M}_{4}$ & 100 & 0 & 45 & 35 & 20 & 175 \\
\hline & $\mathrm{M}_{5}$ & 100 & 0 & 48 & 44 & 8 & 160 \\
\hline & $\mathrm{M}_{6}$ & 100 & 0 & 51 & 32 & 17 & 166 \\
\hline & Mean \pm SD & $98.8 \pm 1.32^{*}$ & & & & & $174.1 \pm 11.9^{*}$ \\
\hline
\end{tabular}

* Significantly different from the negative control $(P<0.001)$.

a Total number of cells with damage (class $1+2+3$ ).

study, artesunate not induced DNA damage in the peripheral blood cells of animals. To the tree tested doses the observed DNA damage was significantly lower than that observed in the negative control group. On the other hand, in liver cells, the $5 \mathrm{mg} / \mathrm{kg}$ and $50 \mathrm{mg} / \mathrm{kg}$ doses were genotoxic; the $100 \mathrm{mg} / \mathrm{kg}$ dose also increased the total number of damaged cells, but this increase was not statistically significant. Among the damaged nucleoids, class 1 comets were predominant. However, in the group treated with doxorubicin, class 2 and 3 comets predominated. Thus, low doses of artesunate were sufficient to produce low genotoxicity in liver cells.

Li et al. (2008) analyzed CHO-9 (Chinese hamster ovary cell line) cells and V79-2 (hamster lung fibroblast cell line) cells with the comet assay and verified that, in vitro, artesunate induced DNA damage and apoptosis. These authors also concluded that, in mammal cells, artesunate generated damage through direct or indirect oxidative stress, resulting in DNA strand breakage. The present study confirms such genotoxicity in vivo and if the generation of reactive oxygen species could be involved in the genotoxicity of artesunate need further studies.

Damage to the DNA molecule, such as adducts and breakage of single or double strands, could become permanent lesions, and the micronucleus test is an excellent means of investigating this type of damage in genetic material (Serpeloni et al., 2008). Furthermore, the micronucleus test can detect cytotoxic effects by the analysis of the PCE/NCE ratio. When the normal proliferation of bone marrow cells is affected by a cytotoxic agent, there is a reduction in the number of immature erythrocytes (PCE) compared to the number of mature erythrocytes (NCE), thus reducing the PCE/NCE ratio (Gollapudi and McFadden, 1995). The PCE/NCE ratios observed in bone marrow cells were not different that observed in control group, indicating that the tested compound no affected the normal proliferation of erythrocytes in bone marrow, which represents a no cytotoxic effect.

The frequency of micronucleated cells was analyzed after $24 \mathrm{~h}$ of treatment (Krishna and Hayashi, 2000). The results indicated that the positive control (Doxorubicin) caused a significant increase $(P<0.001)$ in the number of micronucleated cells compared to the negative control, thus confirming the sensitivity of the test. In the groups treated with artesunate at doses of 50 and $100 \mathrm{mg} /$ $\mathrm{kg}$, there was a statistically significant increase in micronucleated polychromatic erythrocytes compared to control $(P<0.001)$. This means that, under our experimental conditions, artesunate presented clastogenic/aneugenic activity at the two highest doses tested.

Antineoplastic drugs are cytotoxic, and some studies suggest that the cytotoxic activity of artesunate may be effective against cancer by causing damage to cancer cells, delaying the cellular cycle, inhibiting the proliferation of solid tumors, or even inducing apoptosis (Efferth et al., 2003, 2007; Hou et al., 2008; Chen et al., 2010; Du et al., 2010; Cai et al., 2011). Nevertheless, it is necessary to rigorously investigate their safety, given that artesunate presented genotoxic and clastogenic/aneugenic activity in the present study, which might invalidate its use for treating both malaria and cancer. 
Table 2

DNA migration in the comet assay for the assessment of genotoxicity of artesunate in liver cells (collected $24 \mathrm{~h}$ after the treatment) from Swiss mice male (M) in vivo.

\begin{tabular}{|c|c|c|c|c|c|c|c|}
\hline \multirow[t]{2}{*}{ Treatments } & \multirow[t]{2}{*}{ Animals } & \multirow[t]{2}{*}{ Total $^{\mathrm{a}}$} & \multicolumn{4}{|c|}{ Comet class } & \multirow[t]{2}{*}{ Scores } \\
\hline & & & 0 & 1 & 2 & 3 & \\
\hline \multirow[t]{7}{*}{ Control } & $\mathrm{M}_{1}$ & 6 & 94 & 6 & 0 & 0 & 6 \\
\hline & $\mathrm{M}_{2}$ & 9 & 91 & 9 & 0 & 0 & 9 \\
\hline & $\mathrm{M}_{3}$ & 9 & 91 & 8 & 1 & 0 & 10 \\
\hline & $\mathrm{M}_{4}$ & 10 & 90 & 9 & 1 & 0 & 11 \\
\hline & $\mathrm{M}_{5}$ & 7 & 93 & 5 & 2 & 0 & 9 \\
\hline & $\mathrm{M}_{6}$ & 4 & 96 & 4 & 0 & 0 & 4 \\
\hline & Mean \pm SD & $7.5 \pm 2.25$ & & & & & $8.16 \pm 2.63$ \\
\hline \multirow[t]{7}{*}{ Artesunate ( $5 \mathrm{mg} / \mathrm{kg})$} & $\mathrm{M}_{1}$ & 16 & 84 & 16 & 0 & 0 & 16 \\
\hline & $\mathrm{M}_{2}$ & 18 & 82 & 16 & 2 & 0 & 20 \\
\hline & $\mathrm{M}_{3}$ & 21 & 79 & 21 & 0 & 0 & 21 \\
\hline & $\mathrm{M}_{4}$ & 17 & 83 & 17 & 0 & 0 & 17 \\
\hline & $\mathrm{M}_{5}$ & 17 & 83 & 12 & 5 & 0 & 22 \\
\hline & $\mathrm{M}_{6}$ & 16 & 84 & 16 & 0 & 0 & 16 \\
\hline & Mean \pm SD & $17.5 \pm 1.87^{* * *}$ & & & & & $18.6 \pm 2.65^{* *}$ \\
\hline \multirow[t]{7}{*}{ Artesunate $(50 \mathrm{mg} / \mathrm{kg})$} & $\mathrm{M}_{1}$ & 8 & 92 & 8 & 0 & 0 & 8 \\
\hline & $\mathrm{M}_{2}$ & 18 & 82 & 18 & 0 & 0 & 18 \\
\hline & $\mathrm{M}_{3}$ & 11 & 89 & 11 & 0 & 0 & 11 \\
\hline & $\mathrm{M}_{4}$ & 16 & 84 & 16 & 0 & 0 & 16 \\
\hline & $\mathrm{M}_{5}$ & 17 & 83 & 17 & 0 & 0 & 17 \\
\hline & $\mathrm{M}_{6}$ & 15 & 85 & 13 & 2 & 0 & 17 \\
\hline & Mean \pm SD & $14.1 \pm 3.86^{*}$ & & & & & $14.5 \pm 4.03$ \\
\hline \multirow[t]{7}{*}{ Artesunate (100 mg/kg) } & $\mathrm{M}_{1}$ & 9 & 91 & 9 & 0 & 0 & 9 \\
\hline & $\mathrm{M}_{2}$ & 6 & 94 & 6 & 0 & 0 & 6 \\
\hline & $\mathrm{M}_{3}$ & 20 & 80 & 18 & 2 & 0 & 22 \\
\hline & $\mathrm{M}_{4}$ & 11 & 89 & 6 & 5 & 0 & 16 \\
\hline & $\mathrm{M}_{5}$ & 7 & 93 & 7 & 0 & 0 & 7 \\
\hline & $\mathrm{M}_{6}$ & 16 & 84 & 14 & 2 & 0 & 18 \\
\hline & Mean \pm SD & $11.5 \pm 5.46$ & & & & & $13.0 \pm 6.57$ \\
\hline \multirow[t]{7}{*}{ Doxorubicin $(80 \mathrm{mg} / \mathrm{kg})$} & $\mathrm{M}_{1}$ & 96 & 4 & 42 & 39 & 15 & 165 \\
\hline & $\mathrm{M}_{2}$ & 98 & 2 & 43 & 38 & 15 & 164 \\
\hline & $\mathrm{M}_{3}$ & 96 & 4 & 45 & 39 & 12 & 159 \\
\hline & $\mathrm{M}_{4}$ & 97 & 3 & 46 & 34 & 17 & 165 \\
\hline & $\mathrm{M}_{5}$ & 95 & 5 & 42 & 32 & 21 & 169 \\
\hline & $\mathrm{M}_{6}$ & 98 & 2 & 43 & 38 & 17 & 170 \\
\hline & Mean \pm SD & $96.6 \pm 1.21^{* * * *}$ & & & & & $165.3 \pm 3.93^{* * *}$ \\
\hline
\end{tabular}

Significantly different from the negative control $(P<0.05)$

* Significantly different from the negative control $(P<0.01)$.

*** Significantly different from the negative control $(P<0.001)$.

a Total number of cells with damage (class $1+2+3$ ).

Table 3

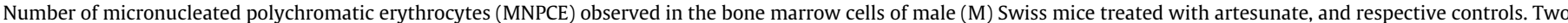
thousand cells were analyzed. SDM = standard deviation of the mean.

\begin{tabular}{|c|c|c|c|c|c|c|c|c|}
\hline \multirow[t]{2}{*}{ Treatments } & \multicolumn{6}{|c|}{ Number of MNPCE per animal } & \multirow[t]{2}{*}{ MNPCE Mean \pm SD } & \multirow[t]{2}{*}{$\mathrm{PCE} / \mathrm{NCE}$ Mean $\pm \mathrm{SD}$} \\
\hline & $\mathrm{M}_{1}$ & $\mathrm{M}_{2}$ & $\mathrm{M}_{3}$ & $\mathrm{M}_{4}$ & $\mathrm{M}_{5}$ & $\mathrm{M}_{6}$ & & \\
\hline Negative control (water) & 3 & 3 & 3 & 2 & 2 & 1 & $2.33 \pm 0.81$ & $1.10 \pm 0.02$ \\
\hline Artesunate $(5 \mathrm{mg} / \mathrm{kg})$ & 2 & 1 & 3 & 4 & 3 & 3 & $2.66 \pm 1.03$ & $1.07 \pm 0.03$ \\
\hline Artesunate (50 mg/kg) & 8 & 5 & 4 & 5 & 8 & 7 & $6.16 \pm 1.72^{*}$ & $1.08 \pm 0.03$ \\
\hline Artesunate $(100 \mathrm{mg} / \mathrm{kg})$ & 6 & 8 & 9 & 7 & 6 & 9 & $7.5 \pm 1.37^{*}$ & $1.1 \pm 0.04$ \\
\hline Doxorubicin $(80 \mathrm{mg} / \mathrm{kg})$ & 83 & 83 & 82 & 83 & 81 & 82 & $82.3 \pm 0.81^{*}$ & $0.98 \pm 0.04^{*}$ \\
\hline
\end{tabular}

* Significantly different from negative control $(P<0.001)$.

In conclusion, the results indicate that artesunate no presents cytotoxic effects but at the higher tested doses, induced clastogenic/aneugenic activity in young bone marrow erythrocytes. And although artesunate no induced DNA damage in cells that do not metabolize as a peripheral blood, at high doses it caused DNA damage in cells that do, such as those in the liver.

\section{Conflict of Interest}

The authors declare that there are no conflicts of interest.

\section{Acknowledgments}

Research supported by the Brazilian agencies CNPq (306544/ 2006-7) and FAPESP - Fundação de Amparo à Pesquisa do Estado de São Paulo (2008/51175-7). We thank Patrícia C. Martins Mello for her technical assistance.

\section{References}

Angus, B.J., Thaiaporn, I., Chanthapadith, K., Suputtamongkol, Y., White, N.J., 2002. Oral artesunate dose-response relationship in acute Falciparum malaria. Antimicrob. Agents Chemother. 46, 778-782. 
Brossi, A., Venugopalan, B., Dominguez, G.L., Yeh, H.J.C., Flippen-Anderson, J.L Buchs, P., Luo, X.D., Milhous, W., Peters, W., 1988. Arteether, a new antimalarial drug: synthesis and antimalarial properties. J. Med. Chem. 31, 645.

Cai, X., You, P., Cai, J., Yang, X., Chen, Q., Huang, F., 2011. ART-induced biophysical and biochemical alterations of Jurkat cell membrane. Micron 42, 17-28.

Chandra, S., Chauhan, L.K.S., Dhawan, A., Murthy, R.C., Gupta, S.K., 2006. In vivo genotoxic effects of industrial waste leachates in mice following oral exposure. Environ. Mol. Mutag. 47, 325-333.

Chen, H., Shi, L., Yang, X., Li, S., Guo, X., Pan, L., 2010. Artesunate inhibiting angiogenesis induced by human myeloma RPMI8226 cells. Int. J. Hematol. 92 587-597.

Dhingra, V.K., Rao, V., Narasu, L.M., 2000. Current status of artemisinin and its derivates as antimalarial drugs. Life Sci. 66, 279-300.

Du, J.H., Zhang, H.D., Ma, Z.J., Ji, K.M., 2010. Artesunate induces oncosis-like cell death in vitro and has antitumor activity against pancreatic cancer xenografts in vivo. Cancer Chemother. Pharmacol. 65, 895-902.

Efferth, T., Sauerbrey, A., Olbrich, A., Gebhart, E., Rauch, P., Weber, H.O., Hengstler, J.G., Halatsch, M.E., Volm, M., Tew, K.D., Ross, D.D., Funk, J.O., 2003. Molecular modes of action of artesunate in tumor cell lines. Mol. Pharmacol. 64, 382-394.

Efferth, T., Giaisi, M., Merling, A., Krammer, P.H., Weber, M.L., 2007. Artesunate induces ROS-mediated apoptosis in doxorubicin-resistant T leukemia cells. PLoS One 2, 693.

Gollapudi, B.B., McFadden, L.G., 1995. Sample size for the estimation of polychromatic to normochromatic erythrocyte ratio in the bone marrow micronucleus test. Mut. Res. 347, 97-99.

Hartmann, A., Speit, G., 1997. The contribution of cytotoxicity to DNA-effects in the single cell gel test (comet assay). Toxicol. Lett. 90, 183-188.

Hou, J., Wang, D., Zhang, R., Wang, H., 2008. Experimental therapy of hepatoma with artemisinin and its derivatives: in vitro and in vivo activity, chemosensitization, and mechanisms of action. Clin. Cancer Res. 14, 5519-5530.

Klayman, D.L., 1985. Qinqhaosu (Artemisinin): an antimalarial drug from China. Science 228, 1049-1055.

Krishna, G., Hayashi, M., 2000. In vivo rodent micronucleus assay: protocol, conduct and data interpretation. Mutat. Res. 455, 155-166.

Li, P.C., Lam, E., Roos, W.P., Zdzienicka, M.Z., Kaina, B., Efferth, T., 2008. Artesunate derived from traditional chinese medicine induces DNA damage and repair. Cancer Res. 68, 4347-4351.

Luxemburguer, C., Nosten, F., Raimond, S.D., Chongsuphajaisiddhi, T., White, N.J., 1995. Oral artesunate in the treatment of uncomplicated hyperparasitemic falciparum malaria. Am. J. Trop. Med. Hyg. 53, 522-525.

Meshnick, S.R., Taylor, T.E., Kamchonwongpaisan, S., 1996. Artemisinin and the antimalarial endoperoxides: from herbal remedy to targeted chemotherapy. Microbiol. Rev. 60, 301-315.

Nosten, F., Luxemburguer, C., ter Kuile, F., Woodrow, C., Eh, J.P. Chongsuphajaisiddhi, T., White, N.J., 1994. Treatment of multidrug-resistant Plasmodium falciparum malaria with 3-day artesunate-mefloquine combination. J. Infect. Dis. 170, 971-977.
Nosten, F., Van Yugt, M., Price, R.N., Luxemburguer, C., Thway, K.L., Brockman, A., ter Kuile, F., Looareesuwan, S., White, N.J., 2000. Effects of artesunate-mefloquine combination on incidence of Plasmodium falciparum malaria and mefloquine resistance in western Thailand: a prospective study. The Lancet 356, 297-302.

Olliaro, P., 2001. Mode of action and mechanism of resistance for antimalarial drug. Pharmacol. Therap. 89, 207-219.

Price, R.N., Nosten, F., Luxemburguer, C., Kham, A., Brockman, A., Chongsuphajaisiddhi, T., White, N.J., 1995. Artesunate versus artemether in combination with mefloquine for the treatment of multidrug-resistant falciparum malaria. Trans. R. Soc. Trop. Med. Hyg. 89, 523-527.

Rodeiro, I., Cancino, L., Gonzàlez, J.E., Morffi, J., Garrido, G., Gonzàlez, R.M., Nuñez, A., Delgado, R., 2006. Evaluation of the genotoxic potential of Mangifera indica L. extract (Vimang), a new natural product with antioxidant activity. Food Chem. Toxicol. 44, 1707-1713.

Schmid, W., 1975. The micronucleus test. Mut. Res. 31, 9-15.

Serpeloni, J.M., Reis, M.B., Rodrigues, J., Santos, L.C., Vilegas, W., Varanda, E.A. Dokkedal, A.L., Colus, I.M., 2008. In vivo assessment of DNA damage and protective effects of extracts from Miconia species using the comet assay and micronucleus test. Mutagenesis 23, 501-507.

Singh, N.P., McCoy, M.T., Tice, R.R., Schneider, E.L., 1988. A simple technique for quantitation of low levels of DNA damage in individual cells. Exp. Cell Res. 175, 184-191.

Sokal, R.R., Rohlf, F.J., 1995. In: Freeman, W.H. (Ed.), Biometry. San Francisco, pp. 175-205. 404-486.

Speit, G., Hartmann, A., 1999. The Comet Assay (Single-Cell Gel Test). In: Methods in Molecular Biology, DNA Repair Protocols: Eukaryotic Systems (Henderson DS, ed.). Humana Press Inc., Totowa 113, 203-212.

Tice, R.R., Agurell, E., Anderson, D., Burlinson, B., Hartmann, A., Kobayashi, H., Miyamae, Y., Rojas, E., Ryu, J.C., Sasaki, Y.F., 2000. Single cell gel/comet assay: guidelines for in vitro and in vivo genetic toxicology testing. Environ. Mol. Mutagen. 35, 206-221.

Vasquez, M.Z., 2010. Combining the in vivo comet and micronucleus assays: a practical approach to genotoxicity testing and data interpretation. Mutagenesis 25, 187-199.

WHO (World Health Organization), 2001. Malaria. Disponível em: <http:// www.rbm.who.int/cmc_upload/0/000/015/367/RBMInfosheet_6.htm>. Access in June, 03, 2008.

WHO (World Health Organization), 2004. Handbook - Non Clinical Safety Testing. Disponível em: <http://www.who.int/tdr/publications/publications/safetyhandbook.htm>. Access in Nov., 03, 2009.

WHO (World Health Organization) 2001. Handbook: Good Laboratory Practice (GLP). Quality practices for regulated non-clinical research and development. Disponível em: <http://apps.who.int/tdr/publications/training-guidelinepublications/good-laboratory-practicehandbook/pdf/glp-handbook.pdf> Access in: May, 10, 2009.

Woodrow, C.J., Haynes, R.K., Krishna, S., 2005. Artemisinins. Postgrad. Med. J. 81, 71-78. 